\title{
RANCANG BANGUN MESIN PENGERING PELLET IKAN TIPE ROTARY DRYER UNTUK KELOMPOK USAHA PETANI (UPET) KABUPATEN CILACAP
}

\author{
Mohammad Nurhilal"1, Bayu Aji Girawan*2, Galih Mustiko Aji”3 \\ 1,2,3 Politeknik Negeri Cilacap \\ Jl. Dr. Soetomo No. 1, Sidakaya, Cilacap \\ 1najiwaa@yahoo.com \\ 2bayuajigirawan@gmail.com \\ 3galihma@gmail.com
}

\begin{abstract}
ABSTRAK
Pellet ikan merupakan makanan ikan buatan sebagai pengganti makanan alami ikan dihabitat aslinya. Makanan buatan ini harus memenuhi persyaratan sesuai dengan SNI diantaranya adalah kadar air yang terkandung dalam pellet. Usaha pengeringan pellet ikan ini adalah menggunakan mesin pengering pellet. Kegiatan Pengabdian Kepada Masyarakat melalui Iptek bagi Masyarakat (IbM) ini adalah menrancang bangun mesin pengering pellet ikan tipe rotary dryer dan kegiatan usaha diseminasi sebagai wadah promosi dalam meningkatkan pemasaran pellet ikan dari kelompok Usaha Petani (UPPET). Hasil rancangan mesin pengering pellet ikan ini mampu menurunkan kadar air sebesar $0,05 \%$ pada kondisi putaran rotary $3 \mathrm{rpm}$, putaran blower $1400 \mathrm{rpm}$, temperatur $\left(\mathrm{T}_{1}\right)=$ $48{ }^{\circ} \mathrm{C}$, dan temperatur $\left(\mathrm{T}_{2}\right)=34{ }^{\circ} \mathrm{C}$, waktu pemanasan 60 menit. Hasil uji mesin pengering yang kedua dengan cara mengurangi sistem ulir di dalam rotary dan menambahkan penutup di ujung rotary serta meninggikan tungku pemanasan dihasilkan temperatur $\left(\mathrm{T}_{1}\right)=60{ }^{\circ} \mathrm{C}$, dan temperatur $\left(\mathrm{T}_{2}\right)=48{ }^{\circ} \mathrm{C}$ serta mampu mengeringkan pellet ikan $0,4 \%$ pada kondisi yang sama yaitu putaran rotary $3 \mathrm{rpm}$, putaran blower $1400 \mathrm{rpm}$.
\end{abstract}

Keywords - pengering pellet, rotary dryer, kadar air pelet

\section{PENDAHULUAN}

Pelet ikan adalah pakan ikan yang dicetak dalam bentuk butiran yang terdiri dari campuran bahan-bahan hewani dan nabati sebagai pengganti makanan alami di habitat aslinya. Pellet ikan yang merupakan makanan pengganti tersebut harus dapat memenuhi kebutuhan nutrisi/gizi bagi ikan. Kecukupan nutrisi tersebut harus dipenuhi ambang batas minimalnya agar ikan dapat tumbuh dan berkembang dengan baik (Kusnadi, 2014).

Sektor perikanan merupakan salah satu komoditi yang sedang berkembang di Kabupaten Cilacap. Potensi lahan tambak sekitar $12.000 \mathrm{Ha}$ yang lokasinya hampir merata di seluruh Kecamatan Kabupaten Cilacap menjadikan sektor perikanan sebagai salah satu sektor yang menjanjikan untuk meningkatkan pendapatan masyarakat.Usaha perikanan yang dilakukan oleh masyarakat diantaranya adalah budidaya ikan dan udang.

Nilai ekonomis dari usaha perikanan sangat bergantung pada biaya yang dikeluarkan. Biaya tersebut meliputi:

1. Biaya kolam dan peralatan Persentase biaya yang harus dikeluarkan untuk kolam dan peralatan adalah sebesar $7 \%$ dari biaya keseluruhan.

2. Biaya pembelian benih Persentase biaya untuk pembelian benih adalah $11 \%$ dari biaya keseluruhan.

3. Biaya pakan

Persentasse biaya yang harus dikeluarkan untuk pembelian benih adalah sebesar 46\% dari biaya keseluruhan.

4. Biaya tenaga kerja

Biaya untuk pembelian benih adalah $36 \%$ dari biaya keseluruhan.

Dari empat komponen biaya tersebut, pakan merupakan komponen biaya terbesar (46\%) 
dari seluruh komponen pembiayaan (Liana, 2015).

Tingginya pengaruh biaya pakan terhadap keuntungan yang diperoleh menjadi suatu permasalahan tersendiri bagi pelaku usaha perikanan. Salah satu cara yang dapat dilakukan untuk memperbesar keuntungan adalah dengancara menekan biaya pengeluaran untuk pakan. Biaya ini dapat ditekan dengan cara memproduksi pelet ikan sendiri dengan memperhatikan faktor-faktor syarat utama yang harus ada, diantaranya adalah kadar air yang ada pada pellet. Pellet dengan kadar air yang rendah mempunyai daya apung lebih lama.Hal ini meminimalisir pellet yang terbuang ke dasar kolam karena tidak dimakan oleh ikan.

\section{TARGET DAN LUARAN}

Target luaran kegiatan IbM ini adalah hasil mesin pengering pellet ikan type rotary dryer kapasitas $100 \mathrm{~kg} / \mathrm{jam}$ dan upaya peningkatan pemasaran pellet ikan pada pelanggan UPET.

Prancangan mesin pengering pellet ikan dalam kegiatan IbM ini lebih memilih pada jenis pengering tipe Rotary Dryer. Dimana, Rotary dryer atau bisa disebut drum dryer merupakan alat pengering berbentuk sebuah drum yang berputar secara kontinyu yang dipanaskan dan dilengkapi dengan tungku atau gasifier. Alat pengering ini dapat bekerja pada aliran udara melalui poros silinder pada temperatur 1200 - 1800 ${ }^{\circ} \mathrm{F}$ tetapi pengering ini lebih seringnya digunakan pada temperatur $400-900$ o $\mathrm{F}$. Rotary dryer sudah sangat dikenal luas di kalangan industri karena proses pengeringannya jarang menghadapi kegagalan baik dari segi output kualitas maupun kuantitas. Namun sejak terjadinya kelangkaan dan mahalnya bahan bakar minyak dan gas, maka teknologi rotary dryer mulai dikembangkan untuk berdampingan dengan teknologi bahan bakar substitusi seperti burner batubara, gas sintesis dan sebagainya. Pengering rotary dryer biasa digunakan untuk mengeringkan bahan yang berbentuk bubuk, granula, gumpalan partikel padat dalam ukuran besar.

Pemasukkan dan pengeluaran bahan selama proses pengeringan terjadi secara berkesinambungan akibat gerakan putaran rotary dan gaya gravitasi. Sumber panas yang digunakan dapat berasal dari uap, dari gas yang memanaskan pipa-pipa pemanas, kemudian uap panas dari pipa pemanas dihembuskan oleh blower yang kemudian mengalir ke dalam rotary. Secara umum, alat rotary dryerterdiri dari sebuah silinder yang berputar di atas sebuah bearing dengan kemiringan yang kecil $\left(5^{\circ}\right)$ menurut sumbu horisontal, rotor, perangkat transmisi, perangkat pendukung,, dan suku cadang lainnya.

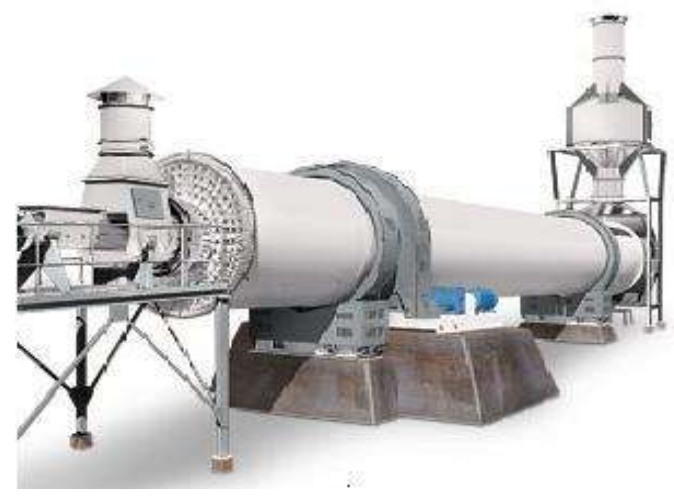

Gambar 1. Mesin pengering tipe rotary dryer

\section{METODE PELAKSANAAN}

Tahapan-tahapan yang dirancang dalam melaksanakan solusi yang ditawarkan untuk mengatasi masalah mitra secara jelas diuraikan dalam flow chart dibawah.

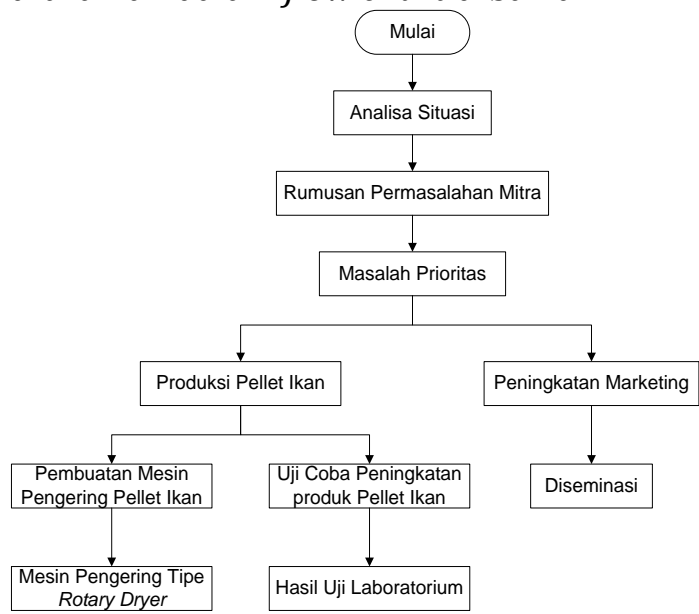

Gambar 2. Flow Chart Tahapan Pelaksanaan Kegiatan IbM

\section{KELAYAKAN PERGURUAN TINGGI}

Pusat Penelitian dan Pengabdian Kepada Masyarakat (PPPM) di Politeknik Negeri 
Cilacap merupakan unit kerja yang salah satu tugasnya membantu kegiatan penelitian dan pengabdian kepada masyarakat yang dilaksanakan oleh Dosen dan Mahasiswa. Kinerja PPPM Politeknik Negeri Cilacap terakhir tahun 2015 membangun beberapa kerjasama dengan instansi dan industri di Kabupaten Cilacap sebagai program Pengabdian kepada Masyarakat bagi Dosen di Lingkungan Politeknik Negeri Cilacap. Beberapa bentuk kerjasama yang dilakukan P3M Politeknik Negeri Cilacap pada tahun 2015 adalah sebagai berikut:

a. Pelatihan robot bagi siswa-siswi SMP

b. Pelatihan Kewirausahaan bagi mitra binaan PT Pelabuhan Indonesia III

c. Pembuatan aplikasi Sistem Informasi Tata Persuratan Dinas Kabupaten Cilacap

d. Bimbingan Teknis Produksi IKM Bengkel Las

e. Mesin Pencacah sampah untuk SMP Negeri 3 Cilacap.

Kepakaran tim pengusul sangat membantu dalam pelaksanaan kegiatan Iptek bagi Masyarakakat. Untuk itu, kepakaran tim yang dibutuhkan harus memiliki kompetensi yang sesuai dengan permasalahan yang dipecahkan. Adapun jenis kepakaran yang dibutuhkan seperti dijelaskan dalam Tabel 1.

TABEL 1 JENIS KEPAKARAN YANG DIBUTUHKAN

DALAM MENGATASI PERMASALAHAN MitRA

\begin{tabular}{|l|l|l|}
\hline No. & \multicolumn{1}{|c|}{ Kepakaran } & \multicolumn{1}{|c|}{ Uraian } \\
\hline 1. & $\begin{array}{l}\text { Desain } \\
\text { perancangan }\end{array}$ & $\begin{array}{l}\text { Membuat gambar } \\
\text { rancangan dengan } \\
\text { software gambar }\end{array}$ \\
\hline 2. & Elemen mesin & $\begin{array}{l}\text { Menghitung elemen- } \\
\text { elemen mesin }\end{array}$ \\
\hline 3. & Permesinan & $\begin{array}{l}\text { Mengoperasikan } \\
\text { mesin-mesin } \\
\text { perkakas }\end{array}$ \\
\hline 4. & Fabrikasi & $\begin{array}{l}\text { Kerja bangku dan } \\
\text { pengelasan }\end{array}$ \\
\hline 5. & $\begin{array}{l}\text { Energi (penggerak, } \\
\text { panas) }\end{array}$ & $\begin{array}{l}\text { Analisa perambatan } \\
\text { panas }\end{array}$ \\
\hline 6. & Motor listrik & $\begin{array}{l}\text { Penggerak sumber } \\
\text { listrik }\end{array}$ \\
\hline 7. & Presentasi & $\begin{array}{l}\text { Komunikasi dalam } \\
\text { lingkungan sosial }\end{array}$ \\
\hline
\end{tabular}

\section{HASIL DAN LUARAN YANG DICAPAI}

\subsection{Hasil rancangan Mesin}

Spesifikasi mesin pengering tipe rotary dryer seperti pada Tabel di bawah.

TABEL 2. SPESIFIKASI MESIN PENGERING TIPE ROTARY DRYER.

\begin{tabular}{|c|c|}
\hline & $\begin{array}{l}\text { Engine: } \\
\text { Motor AC 1,5 HP, } 1 \text { Phase } \\
\text { Gear box : } 1: 60\end{array}$ \\
\hline & $\begin{array}{l}\text { Transmisi } \\
\text { Chain RS. } 60 \\
\text { V-belt B- } 46=2 \text { buah }\end{array}$ \\
\hline & $\begin{array}{l}\text { Rangka } \\
\text { Baja konstruksi cannal } 60 \text { x } 40\end{array}$ \\
\hline & $\begin{array}{l}\text { Rotary drum } \\
\text { Plat } 2 \mathrm{~mm} \text { roll, } \mathrm{d}=500 \mathrm{~mm} \times 5 \mathrm{~m}\end{array}$ \\
\hline & $\begin{array}{l}\text { Hopper } \\
\text { Plat } 2 \mathrm{~mm} 600 \mathrm{~mm} \times 500 \mathrm{~mm}\end{array}$ \\
\hline & $\begin{array}{l}\text { Sistem pemanas } \\
\text { Chasing tungku plat } 4 \mathrm{~mm} \\
\text { Heat exchanger : pipa } 11 / 2 \text { inchi }=18 \text { buah } \\
\text { Bahan bakar : gas atau kayu bakar } \\
\text { Cerobong : pipa } 6 \text { inchi, tinggi } 3,8 \mathrm{~m} \\
\text { Saluran keluar panas : Pipa } 6 \text { inchi } \\
\text { Blower : Diameter } 12 \text { inchi, rotasi } 1400 \mathrm{rpm} \text {, } \\
\text { daya } 35 \mathrm{~W} \text {, dan volatge } 220 \text { Volt } \\
\text { Roda penggerak } 6 \text { inchi }=10 \text { buah }\end{array}$ \\
\hline & $\begin{array}{l}\text { Disc charg } \\
\text { Steel plat } 2 \mathrm{~mm}\end{array}$ \\
\hline & $\begin{array}{l}\text { Sistem kontrol panas : } \\
\text { Temperatur } 20^{\circ} \mathrm{C}-100^{\circ} \mathrm{C} \\
\text { Sensor LM35 }=2,8 \text { bit analog digital control } \\
\text { LCD display } 2 \times 16 \text { karakter } \\
\text { Resolution } 0,5{ }^{\circ} \mathrm{C}\end{array}$ \\
\hline
\end{tabular}

Berdasarkan studi literatur dan studi lapangan yang, maka dilakukan perancangan untuk alat pengering pellet ikan seperti yang terlihat pada gambar 2 .

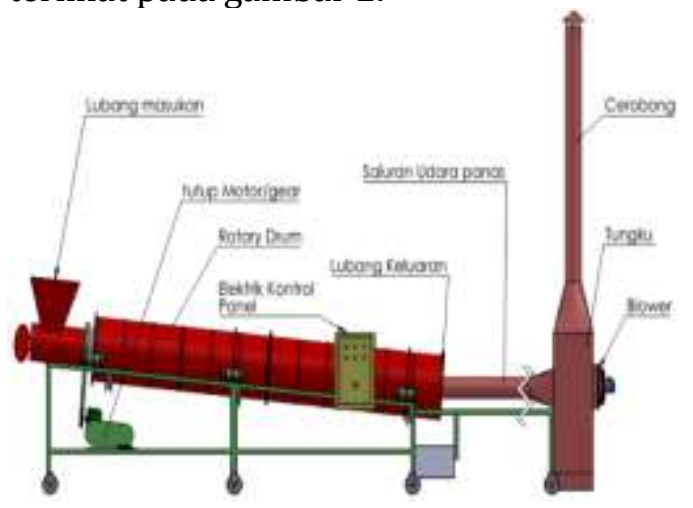

Gambar 3. Rancangan pengering pelet ikan tipe rotary dryer model 1

Ambang batas kandungan nutrisiuntuk pelet ikan diatur dalam SNI tahun 2016, yang meliputi: 
a. Kandungan protein berkisar $20-35 \%$

b. Kandungan lemak berkisar $2-10 \%$

c. Kandungan abu kurang dari $12 \%$

d. Kandungan air kurang dari $12 \%$

Pembuatan pellet ikan dimulai dengan menimbang bahan-bahan sesuai dengan komposisi yang diperlukan, kemudian diaduk dengan rata dan ditambahkan air panas ke dalam adukan yang bertujuan agar bahan-bahan dapat tercampur dengan baik (Dani, 2005). Selain dengan air panas, proses pencampuran dan pengadukan dapat juga menggunakan air dingin, kemudian adonan dikukus pada temperatur $80^{\circ} \mathrm{C}$ selama 3 menit (Zaenuri, 2015).

Adonan selanjutnya dimasukkan ke dalam mesin pencetak pellet, untuk proses pembentukan dimana bentuk dan dimensi pellet tergantung pada alat pencetaknya. Pellet yang sudah dicetak harus dikeringkan terlebih dahulu untuk menurunkan kadar air. Proses pengeringan pellet dapat dilakukan di bawah sinar matahari, maupun menggunakan alat pengering buatan. Pengurangan kadar air dihitung menggunakan persamaan:

$M_{w b}=\frac{w_{0}-w_{d}}{w_{0}}$

Dimana:

$$
\begin{aligned}
\mathrm{M}_{\mathrm{wb}}= & \text { kadar air basis basah (\%) } \\
\mathrm{w}_{0}= & \text { massa awal pellet } \\
& \text { dikeringkan (kg) } \\
\mathrm{w}_{\mathrm{d}}= & \begin{array}{l}
\text { massa akhir pelum } \\
\text { dikeringkan (kg) }
\end{array}
\end{aligned}
$$

Sebuah alat pengering pellet dengan menggunakan proses aerasi melakukan pengeringan pellet dengan kapasitas $500 \mathrm{~kg}$ di bawah temperatur $82-88^{\circ} \mathrm{C}$. Dari mesin tersebut diperoleh waktu pengeringan sebesar 3 jam, sedangkan jika dilakukan pengeringan menggunakan sinar matahari diperlukan waktu 6 jam (Siregar, 2011).

Sebuah oven untuk pengering eceng gondok dengan metode vakum menggunakan pemanas berbahan bakar LPG mampu mengeringkan eceng gondok dengan kandungan air 91\% menjadi 7,2\%. Pengeringan tersebut optimal pada temperatur $70^{\circ} \mathrm{C}$ dengan waktu 180 menit. Pengering dengan pemanas berbahan bakar LPG merupakan alternatif pengering yang hemat jika dibandingkan dengan pemanas menggunakan energi listrik

(Prasetyaningrum, 2010).

Sebuah pengering tipe cabinet dryer yang merupakan alat pengering yang menggunakan udara panas dalam ruang tertutup (chamber) dengan memanfaatkan uap air sebagai pembawa kalor untuk mengeringkan kakao. Pemanas yang digunakan adalah pemanas berbahan bakar kerosin. Alat ini mampu mengurangi kandungan air kakao dari $60 \%$ menjadi $6,45 \%$ dengan kapasitas pengeringan sebesar $7,5 \mathrm{~kg}$ dalam waktu 10 jampada temperatur $70^{\circ} \mathrm{C}$ (Napitupulu, 2012).

Sebuah alat pengering ikan dengan kapasitas $16 \mathrm{~kg}$ menggunakan pemanas hybrid dari tenaga surya dan kompor. Proses pengeringan dilakukan pada temperatur rata-rata $40^{\circ} \mathrm{C}$ selama 14 jam mampu menurunkan kandungan air pada ikan yang semula 70\% menjadi 40\% (Bintang, 2013).

\subsection{Hasil pengujian}

Pengujian pada pellet ikan dengan kebasahan $100 \%$ (2000 gram bahan + 2000 gram air ), dimana pada kondisi putaran rotary $3 \mathrm{rpm}$, putaran blower $1400 \mathrm{rpm}$, temperatur $\left(\mathrm{T}_{1}\right)=48{ }^{\circ} \mathrm{C}$, dan temperatur $\left(\mathrm{T}_{2}\right)$ $=34{ }^{\circ} \mathrm{C}$, waktu pemanasan 60 menit, dimana dihasilkan berat akhir pellet ikan adalah 3,8 Kg. Jadi kadar air basis basah adalah :

$$
M_{w b}=\frac{4000-3800}{4000}=0,05 \%
$$

Jadi, pada spesifikasi hasil rancangan mesin pengering ini hanya mampu mengeringkan sampai 0,05\%. Hasil ini lebih dipengaruhi oleh beberapa faktor, di antaranya adalah :

1. Ulir pada rotary : jumlah ulir dalam rotary yang terlalu banyak sehingga dapat menghalangi penyerapan uap panas pada dinding rotary, sehingga perlu di mengurangi jumlah ulir di bagian dalam rotary

2. Kontrol pemanas : kontrol pemanas yang kurang merespon pembacaan temperatur di ruang rotary, untuk itu perlu penggantian sistem kontrol.

3. Penutup rotary : bagiann ujung rotary (dari pipa penyalur uap panas dengan rotary) masih terbuka, 
sehingga udara luar dapat masuk kedalam rotary, sehingga perlu menambahkan penutup

4. Jarak api pemanas dengan pipa pemanas masih terlalu jauh sehingga proses pemanasan pipa masih cenderung lama, untuk itu jarak sumber pemanas dengan pipa-pipa di atur kembali.

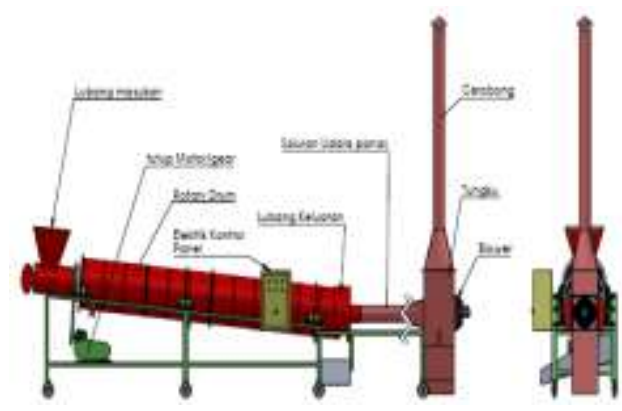

Gambar 4. Rancangan pengering pelet ikan tipe rotary dryer model 2

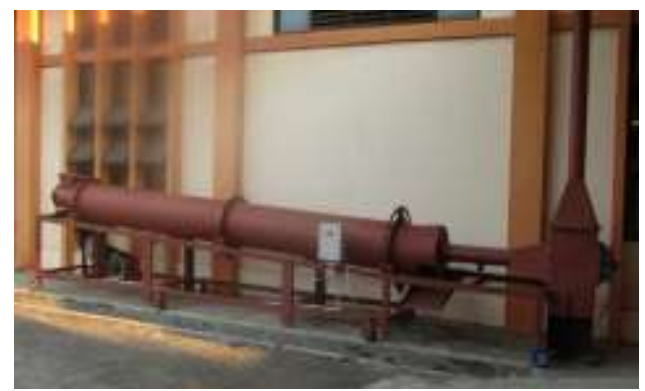

Gambar 4. Hasil Mesin pengering pelet ikan tipe rotary dryer

Hasil perbaikan mesin di peroleh desain dan rancangan mesin pengering pellet ikan seperti ditunjukan pada gambar 2. Pengujian pada pellet ikan dengan kebasahan $100 \%$ (2000 gram bahan + 2000 gram air ), dimana pada kondisi putaran rotary $3 \mathrm{rpm}$, putaran blower $1400 \mathrm{rpm}$, temperatur $\left(\mathrm{T}_{1}\right)=60{ }^{\circ} \mathrm{C}$, dan temperatur $\left(\mathrm{T}_{2}\right)=48{ }^{\circ} \mathrm{C}$, waktu pemanasan 60 menit, dimana dihasilkan berat akhir pellet ikan adalah 2,4 Kg. Jadi kadar air basis basah adalah :

$$
M_{w b}=\frac{4000-2400}{4000}=0,4 \%
$$

Jadi, pada spesifikasi hasil rancangan mesin pengering ini mampu mengeringkan sampai $0,4 \%$.

\section{KESIMPULAN DAN SARAN}

\section{Kesimpulan}

Kesimpulan yang dapat diambil hasil kegiatan Iptek bagi Masyarakat ini adalah :

1. Hasil rancangan akhir mesin pengering pellet ikan tipe rotary dryer masih perlu di kembangkan, dengan menambahkan pelat diberi lubanglubang di tempatkan dibagian atas pipa-pipa pemanas, agar tidak banyak uap panas yang terbuang.

2. Hasil uji pengeringan pellet ikan didapat $0,4 \%$ atau penurunan berat awal 1600 gram selama 60 menit.

3. Kegiatan diseminasi pengering pellet ikan diharapkan dapat sebagai sarana promosi kepada peserta yang merupakan pelanggan UPET.

\section{Saran}

Saran yang dapat diberikan dari hasil kegiatan Iptek bagi Masyarakat adalah :

1. Mesin pengering pellet ikan tipe rotary dryer ini dapat dikembangkan baik dari segi sistem pemanas maupun dari sisi konstruksinya, sehingga dapat diaplikasikan sesuai dengan kapasitas pengeringan

2. Usaha produksi pellet ikan ini masih perlu perhatian dari pihak pemerintah maupun swsta untuk pengembangan produksi, dikarenakan bahan baku yang digunakan masih memanfaatkan limbah pertanian dan rumah tangga.

\section{UCAPAN TERIMA KASIH}

Pelaksana Kegiatan pengabdian kepada masyarakat mengucapkan terima kasih keppada Kemenristek Dikti atas pendanaan kegiatan inii melalui skema Iptek bagi Masyarakat. Selanjutnya PPPM Politeknik Negeri Cilacap yang membantu terlaksananya kegiatan ini, sertamitra kegiatan ini yaitu kelompok Usaha Petani (UPET) atas kerjasamanya.

\section{DAFTAR PUSTAKA}

Liana, L., 2015. Analisis Usaha Budidaya Perikanan Air Tawar di Kabupaten Kampar Provinsi Riau. Dinamika Pertanian, 30(1), pp.53-60. 
Kusnadi, H., 2014. "Pelatihan Pembuatan Pakan Ikan Lele, Mas dan Nila", Makalah Balai Pengkajian Teknologi Pertanian, Bengkulu.

Indonesia, S.N., 2009. Produksi ikan nila Oreochromis niloticus Bleeker kelas pembesaran di kolam air tenang. Badan Standardisasi Nasional/BSN. SNI, 7550, p.2009.

Dani, N.P., Budiharjo, A. and Listyawati, S., 2005. Komposisi Pakan Buatan Untuk Meningkatkan Pertumbuhan Dan Kandungan Protein Ikan Tawes (Puntius Javanicus Blkr.) Blkr. BioSMART: Journal of Biological Science, 7(02).

Zaenuri, R., Suharto, B. and Sutanhaji, A.T., 2014. Kualitas pakan ikan berbentuk pelet dari limbah pertanian. Jurnal Sumber Daya Alam dan Lingkungan, 1(1), pp.31-36.

Siregar, H.P., 2011. "Drying Box Pelet Pakan Ikan untuk Usaha Kecil Menengah", Prosiding Seminar Nasional Teknik Kimia Kejuangan, pp. F 10-1 - F10-4.

Prasetyaningrum, A., 2010. Rancang Bangun Oven Drying Vacuum dan Aplikasinya sebagai Alat Pengering pada Syhu Rendah. Jurnal Riptek, 4(1), pp.45-53.

Napitupulu, F.H. and Tua, P.M., 2012. Perancangan dan Pengujian Alat Pengering Kakao dengan Tipe Cabinet Dryer untuk Kapasitas 7, 5 Kg PerSiklus. Jurnal Dinamis, (10).

Bintang, Y.M., Pongoh, J. and Onibala, H., 2013. Konstruksi dan Kapasitas Alat Pengering Ikan Tenaga Surya Sistem Bongkar-Pasang. Jurnal Media Teknologi Hasil Perikanan, 1(2). 